\title{
Localization of binding sites for IGF-I, insulin and GH in the sow ovary
}

\section{H Quesnel}

Institut National de la Recherche Agronomique, Station de Recherches Porcines, 35590 Saint-Gilles, France

\begin{abstract}
Binding sites for IGF-I, insulin, and GH were localized by in situ binding of ${ }^{125}$ I-labelled hormones to the different compartments of the sow ovary. Binding sites for IGF-I were detected in oocytes, granulosa and thecal cells of healthy and atretic follicles as well as in the antrum and the stroma. Competition of ${ }^{125}$ I-labelled IGF-I with IGF-I, insulin and an analogue of IGF-I (Long $\mathrm{R}^{3}$ IGF-I), which allowed discrimination between binding to binding proteins from binding to type-I receptors, suggested that type-I receptors were present in granulosa cells of healthy follicles, whilst binding in other compartments was mainly due to binding proteins. Binding of insulin was revealed in oocytes, granulosa and theca interna cells of healthy preantral and antral follicles, and, to a lesser extent, in
\end{abstract}

theca externa and stromal cells, and was still observed in granulosa cells of atretic follicles. Labelling with ${ }^{125} \mathrm{I}-$ labelled bovine $\mathrm{GH}$ was demonstrated in oocytes, granulosa cells, theca interna cells, and, although less intense, in theca externa and stromal cells. It disappeared in granulosa cells during atresia. Binding sites for $\mathrm{GH}$ were detected at all follicular stages, from preantral to preovulatory stages, but the intensity of labelling in granulosa cells was more intense in preantral than in large follicles. These data support the participation of insulin, GH and IGF-I in oocyte maturation, follicular growth and stromal cell function in swine.

Journal of Endocrinology (1999) 163, 363-372

\section{Introduction}

Ovarian follicular growth and differentiation is controlled by pituitary gonadotrophins, luteinizing hormone and follicle-stimulating hormone, and by local factors, such as steroids and growth factors. In numerous species, evidence has been provided that nutrition may influence ovarian function, and in pigs some observations suggested that nutritional effects alter folliculogenesis, not only through gonadotrophin-mediated effects, but also through direct effects at the ovarian level (reviewed by Cosgrove \& Foxcroft 1996, Cox 1997). Insulin, insulin-like growth factor-I (IGF-I) and growth hormone (GH) have been proposed as metabolic mediators of these latter effects for several reasons. First, their systemic concentrations are closely dependent upon nutrition. Secondly, they may stimulate or inhibit ovulation and increase the ovulation rate when administrated to prepubertal or cyclic gilts or to reproductive sows (insulin: Cox et al. 1987, Ramirez et al. 1997, IGF-I: Okere et al. 1996, GH: Kirkwood et al. 1988). Thirdly, in vitro studies in various species provided evidence that these hormones can alter the activity of follicular cells, either in synergy with gonadotrophins, or alone. Thus, GH accelerates in vitro differentiation of cultured granulosa cells, mainly by amplification of gonadotrophin action (Jia et al. 1986, Hsu \& Hammond 1987), but GH alone may also stimulate steroid production
(Hsu \& Hammond 1987, Manson et al. 1990). Insulin and IGF-I stimulate granulosa cell mitogenesis and steroidogenesis of follicular cells (Adashi et al. 1985). These effects are mediated by specific receptors and these receptors, or their mRNAs, have been detected in the ovaries of numerous species, including the pig (Giudice 1992). However, in this latter species, localization of these receptors in the different ovarian compartments has never been fully described. Thus, the aim of the present study was to localize the binding sites for GH, insulin and IGF-I in follicles and corpora lutea in the female pig.

\section{Materials and Methods}

\section{Materials}

Large White gilts (INRA, Saint-Gilles, France) had their oestrous cycles synchronized with a progesterone agonist, Regumate (Roussel Uclaf, Romanville, France). Ovaries were removed by laparotomy conducted under general anaesthesia at days 4 (late follicular phase, three sows) or 10 (early luteal phase, two sows) after the last day of treatment. Ovaries of two gestating gilts were removed at slaughter at day 104 of gestation. They were coated with cryoprotectant embedding medium (Tissue-Tek, Miles Laboratories, Elkhart, IN, USA), frozen in liquid nitrogen and stored at $-80{ }^{\circ} \mathrm{C}$. 
Purified bovine GH (bGH) (USDA-bGH-B1; USDA Animal Hormone Program, Beltsville, MD, USA) was iodinated by the chloramine- $\mathrm{T}$ method to a specific activity of $40-50 \mu \mathrm{Ci} / \mu \mathrm{g}$. This radioligand was used rather than porcine $\mathrm{GH}(\mathrm{pGH})$ because it has been previously shown that specific binding in porcine tissue was higher with ${ }^{125}$ I-labelled bGH than with homologous ${ }^{125} \mathrm{I}$ labelled pGH (Breier et al. 1989). bGH was also used as unlabelled ligand. Recombinant human (rh) IGF-I and IGF-II, and Long $\mathrm{R}^{3}$ IGF-I (LR ${ }^{3}$ IGF-I), a potent analogue of rhIGF-I, were supplied by GroPep Pty Ltd (Adelaide, SA, Australia). rhIGF-I was iodinated by the chloramine- $\mathrm{T}$ method to a specific activity of 150 $160 \mu \mathrm{Ci} / \mu \mathrm{g}$. Iodinated porcine insulin (INSI-TRA, approximate specific activity $300 \mu \mathrm{Ci} / \mu \mathrm{g}$ ) was purchased from CIS Bio International (Gif-sur-Yvette, France) and unlabelled insulin from porcine pancreas from Sigma ( $\mathrm{St}$ Louis, MO, USA).

\section{Binding assays on histological sections}

Binding of iodinated hormones was detected by an autoradiographic method adapted from Monget et al. (1989). Frozen ovaries were cut into $8 \mu \mathrm{m}$ thick serial sections with a cryomicrotome. After fixation for $10 \mathrm{~min}$ at $4{ }^{\circ} \mathrm{C}$ in $4 \%$ paraformaldehyde-PBS (0.01 M, pH 7.4) and three subsequent washes in cold $\mathrm{PBS}$, sections were stored at $4{ }^{\circ} \mathrm{C}$ for a maximum of $48 \mathrm{~h}$ and then circled with a special pen (PAP pen, Labonord, Templemars, France). They were incubated for $30 \mathrm{~min}$ at $4{ }^{\circ} \mathrm{C}$ in $200 \mu \mathrm{l}$ incubation buffer, then overnight at $4{ }^{\circ} \mathrm{C}$ in $200 \mu$ incubation buffer containing the ${ }^{125} \mathrm{I}$-labelled ligand $\left(10^{5}\right.$ c.p.m. $\left./ 100 \mu \mathrm{l}\right)$. The incubation buffers were Tris $25 \mathrm{mM}, \mathrm{CaCl}_{2} 10 \mathrm{mM}$, BSA $0.5 \%, \mathrm{NaN}_{3} 0.02 \%, \mathrm{pH} 7 \cdot 4$ for $\mathrm{bGH}$ and Tris $50 \mathrm{mM}, \mathrm{MgCl}_{2} 5 \mathrm{mM}$, BSA $0 \cdot 5 \%, \mathrm{NaN}_{3} 0 \cdot 02 \%, \mathrm{pH} 7 \cdot 4$ for IGF-I and insulin. To determine nonspecific binding, for each ligand tested, an adjacent serial section of ovary was incubated with an excess of unlabelled ligand (400, 300 and $200 \mathrm{ng} / 100 \mu \mathrm{l}$ for bGH, IGF-I and insulin respectively). To discriminate IGF-I binding to IGFbinding proteins (IGFBPs) from binding to type-I receptor ('IGF-I receptor'), displacements were performed with various ligands. Indeed, it has been demonstrated in several species that IGF-I binding on receptors may be completely displaced by an excess of IGF-I, IGF-II or LR ${ }^{3}$ IGF-I, or partially displaced by a large amount of insulin, whereas IGF-I binding to IGFBPs could not be removed by LR $^{3}$ IGF-I (Francis et al. 1992) or insulin, even in large excess (reviewed by Giudice 1992). After incubation, sections were washed three times in PBS, postfixed in 3\% glutaraldehyde-PBS, washed in PBS and air dried for $2 \mathrm{~h}$. For autoradiography, they were dipped into Kodak NTB2 emulsion diluted 1:1 with distilled water, air dried and exposed at $4{ }^{\circ} \mathrm{C}$ for 4 or 10 days. The emulsion was developed and fixed according to the manufacturer's instructions, then the sections were counterstained with
Harris' haematoxylin solution and mounted. Sections were observed using a Leitz Orthoplan microscope (Leica, Rueil Malmaison, France) in darkfield to see silver grains or in brightfield to see cells. The intensity of staining for each compartment was compared within sections or within experiments.

To assess the quality of the follicles, some sections were fixed in methanol-formaldehyde-acetic acid (80:15:5) and stained with Feulgen reagent. Follicles were classified as early atretic and atretic when few (at least four) or numerous pycnotic granulosa cells were found on the section respectively. When almost all granulosa cells were pycnotic, follicles were classified as late atretic.

Hormone binding to follicles was examined in ovaries taken 4 days after Regumate treatment (during the follicular phase) and binding to corpora lutea in ovaries removed 10 days after the treatment (during the early luteal phase) and during late gestation.

\section{Results}

\section{Binding sites for IGF-I}

Binding sites for IGF-I were widespread in the ovary. They were detected in all the oocytes examined $(n=20)$. They were also observed in granulosa cells and theca interna and externa cells of healthy and atretic follicles as well as in the antrum, in corpora lutea and in the stroma (Figs 1, 2 and 3; Table 1).

Binding of ${ }^{125}$ I-labelled IGF-I in granulosa cells of healthy follicles was partially displaced by LR $^{3}$ IGF-I (Fig. 2). Binding in thecal cells (interna and externa) of healthy and atretic follicles and in granulosa cells of atretic follicles was not displaced, or only poorly displaced, by $\mathrm{LR}^{3}$ IGF-I. In corpora lutea of gestation, IGF-I labelling in large luteal cells was displaced by IGF-I (completely) and IGF-II (partially), and was poorly displaced by LR $^{3}$ IGF-I or by insulin in excess (Fig. 3).

\section{Specific binding sites for insulin}

A slight labelling was observed in six out of nine oocytes examined. Labelling was more intense in granulosa and theca interna cells of healthy follicles, and less marked in theca externa and stroma (Fig. 4; Table 1). In atretic follicles, binding was observed in both granulosa cells and thecal cells (Fig. 4). Labelling was present in luteal cells of cyclic or gestating corpora lutea (Fig. 5). No labelling was found in the antrum.

\section{Specific binding sites for $\mathrm{GH}$}

Specific labelling was found in granulosa, thecal and stromal cells (Fig. 6, Table 1). All the oocytes observed 


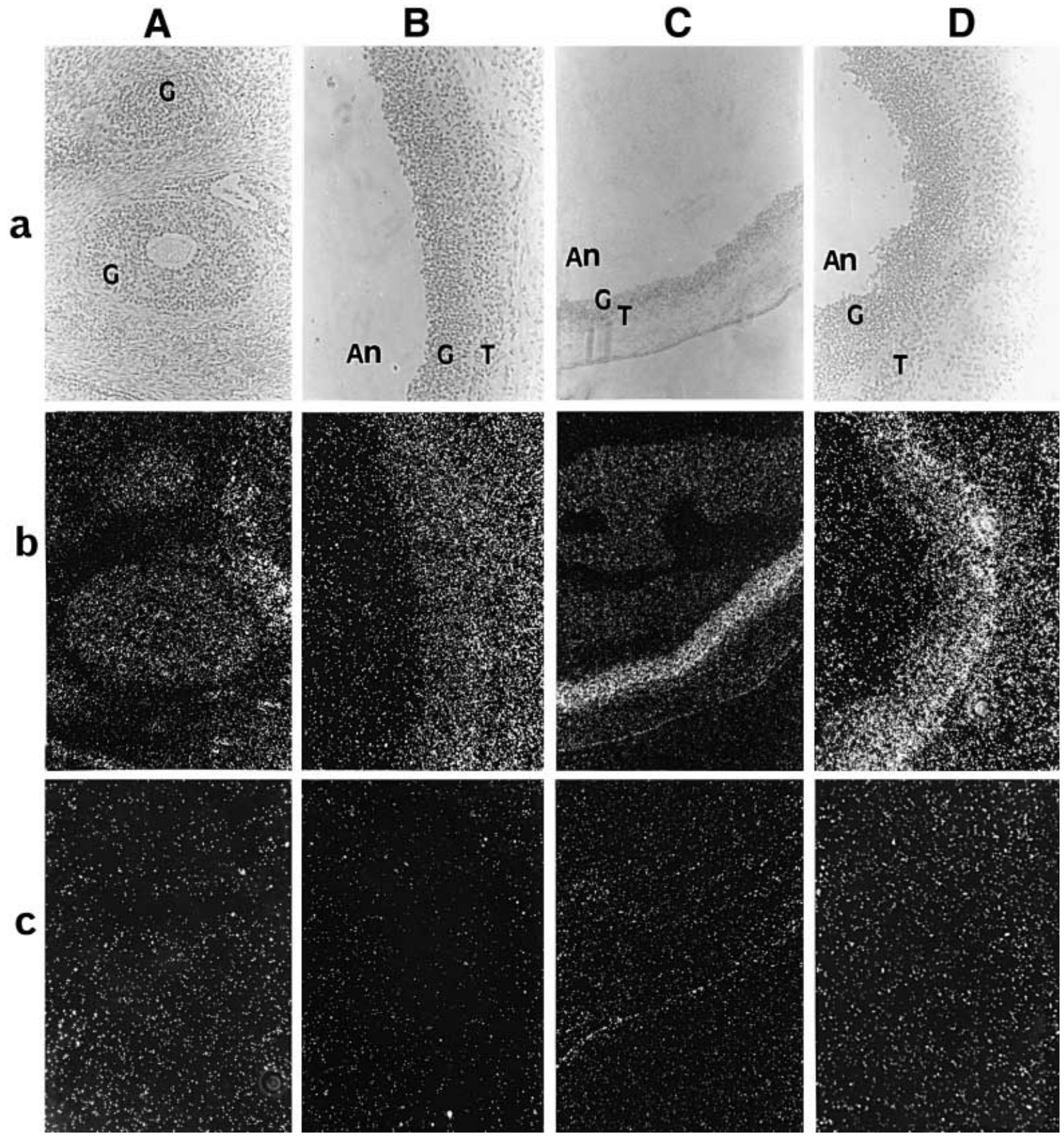

Figure 1 Binding of radiolabelled IGF-I to different compartments of the swine ovary. The hormone may bind the type-I receptor and IGFBPs. (A) Preantral follicles; (B) small antral follicle $(2 \mathrm{~mm})$; (C) large antral follicle $(7 \mathrm{~mm})$; (D) atretic follicle. (a, b) Total binding; (c) nonspecific binding to these same follicles (these sections were incubated with ${ }^{125}$ I-labelled IGF-I and an excess of IGF-I (300 ng/100 $\mu$ l) simultaneously). (a) brightfield; (b, c) darkfield ( $\times$ 74). An: antrum, G: granulosa cells, T: theca interna cells.

were also labelled ( $n=30$, Fig. 6$)$. In healthy follicles, both granulosa and thecal cells presented binding sites for GH (Fig. 6). In early atretic follicles, granulosa cells still presented a clear labelling, which disappeared in late atretic follicles (Fig. 6). Binding sites were detected in all follicular stages, from preantral to preovulatory stages. However, the intensity of labelling in granulosa cells was more intense in preantral follicles than in large follicles. 
Table 1 Binding sites for ${ }^{125}$ I-labelled insulin, IGF-I and bGH in preantral, small (1-3 mm) and large (>5 mm) healthy follicles, in atretic follicles and in corpora lutea during mid-luteal phase or late gestation. Binding sites for IGF-I consist of type-I receptors and IGFBPs

\begin{tabular}{|c|c|c|c|c|c|c|c|c|c|c|c|c|}
\hline & \multicolumn{4}{|c|}{ IGF-I } & \multicolumn{4}{|c|}{ Insulin } & \multicolumn{4}{|c|}{ GH } \\
\hline & $n$ & $\begin{array}{l}\text { Granulosa } \\
\text { cells }\end{array}$ & $\begin{array}{l}\text { Theca } \\
\text { interna } \\
\text { cells }\end{array}$ & $\begin{array}{l}\text { Theca } \\
\text { externa } \\
\text { cells }\end{array}$ & $n$ & $\begin{array}{l}\text { Granulosa } \\
\text { cells }\end{array}$ & $\begin{array}{l}\text { Theca } \\
\text { interna } \\
\text { cells }\end{array}$ & $\begin{array}{l}\text { Theca } \\
\text { externa } \\
\text { cells }\end{array}$ & $n$ & $\begin{array}{l}\text { Granulosa } \\
\text { cells }\end{array}$ & $\begin{array}{l}\text { Theca } \\
\text { interna } \\
\text { cells }\end{array}$ & $\begin{array}{l}\text { Theca } \\
\text { externa } \\
\text { cells }\end{array}$ \\
\hline \multicolumn{13}{|l|}{ Follicular phase } \\
\hline Preantral follicle & 26 & + & + & \pm & 13 & + & + & \pm & 73 & + & + & - \\
\hline Small follicle & 17 & + & + & \pm & 20 & + & + & \pm & 30 & + & + & \pm \\
\hline Atretic follicle & 7 & + & + & \pm & \multirow{2}{*}{\multicolumn{4}{|c|}{ Luteal cells }} & 16 & - & - & - \\
\hline & & \multicolumn{3}{|c|}{ Luteal cells ${ }^{\mathrm{a}}$} & & & & & \multicolumn{4}{|c|}{ Luteal cells } \\
\hline Luteal phase & 6 & \multicolumn{3}{|c|}{+} & 6 & \multicolumn{3}{|c|}{+} & \multicolumn{4}{|c|}{$\mathrm{Nd}$} \\
\hline Gestation & 6 & \multicolumn{3}{|c|}{+} & 6 & \multicolumn{3}{|c|}{+} & \multicolumn{4}{|c|}{$\mathrm{Nd}$} \\
\hline
\end{tabular}

aMixed large and small luteal cells.

Intensity of staining: + intense; \pm weak; - undetected.

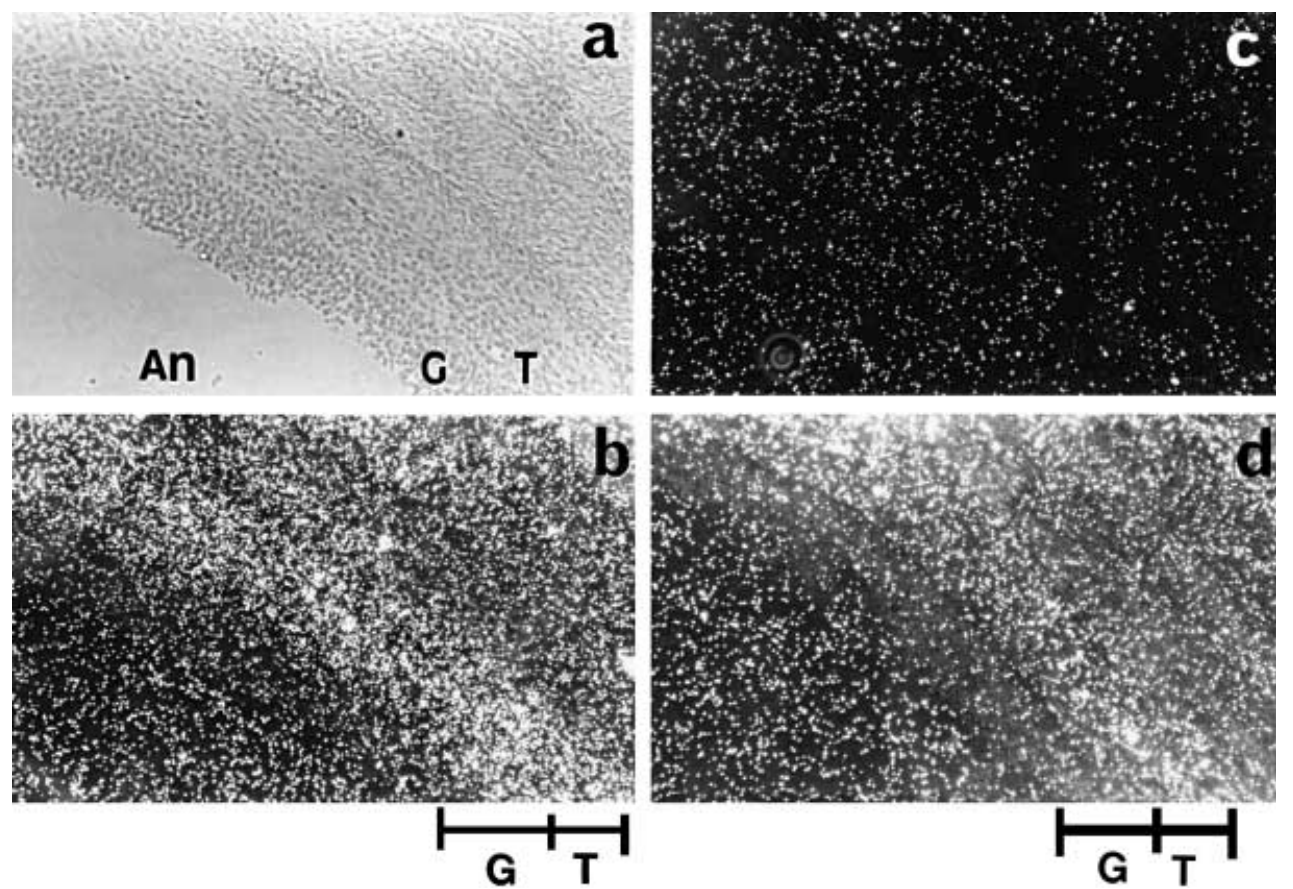

Figure 2 Binding of radiolabelled IGF-I to a healthy medium-sized follicle $(3 \mathrm{~mm})$. (a, b) Total binding; (c, d) nonspecific binding to the same follicle (these sections were incubated with ${ }^{125}$ I-labelled IGF-I and an excess of IGF-I (300 ng/100 $\mu \mathrm{l}$, (c)) or an excess of LR IGF-I (400 ng/100 $\mu \mathrm{l}$, (d) simultaneously). Labelling in granulosa cells was partially displaced by LR ${ }^{3}$ IGF-I. (a) Brightfield; (b-d) darkfield $(\times 74)$. An: antrum, G: granulosa cells, T: theca interna cells.

\section{Discussion}

To our knowledge, no attempt to localize binding sites for insulin and GH in the different compartments of the swine ovary has been previously reported. Therefore, we have localized simultaneously binding sites for IGF-I, insulin and GH by in situ binding on frozen ovarian sections. Our results show the presence of binding sites for IGF-I in oocytes, granulosa and thecal cells (interna and externa) of preantral follicles, antral healthy follicles and atretic follicles, as well as in the stroma. Since IGF-I binding on granulosa cells of healthy follicles was partially, but clearly, displaced by the IGF-I analogue $\mathrm{LR}^{3} \mathrm{IGF}-\mathrm{I}$, these binding sites are likely to be, at least in part, type-I receptors. In pigs, previous studies have revealed two classes of specific IGF-I-binding sites in granulosa cells from small, medium 

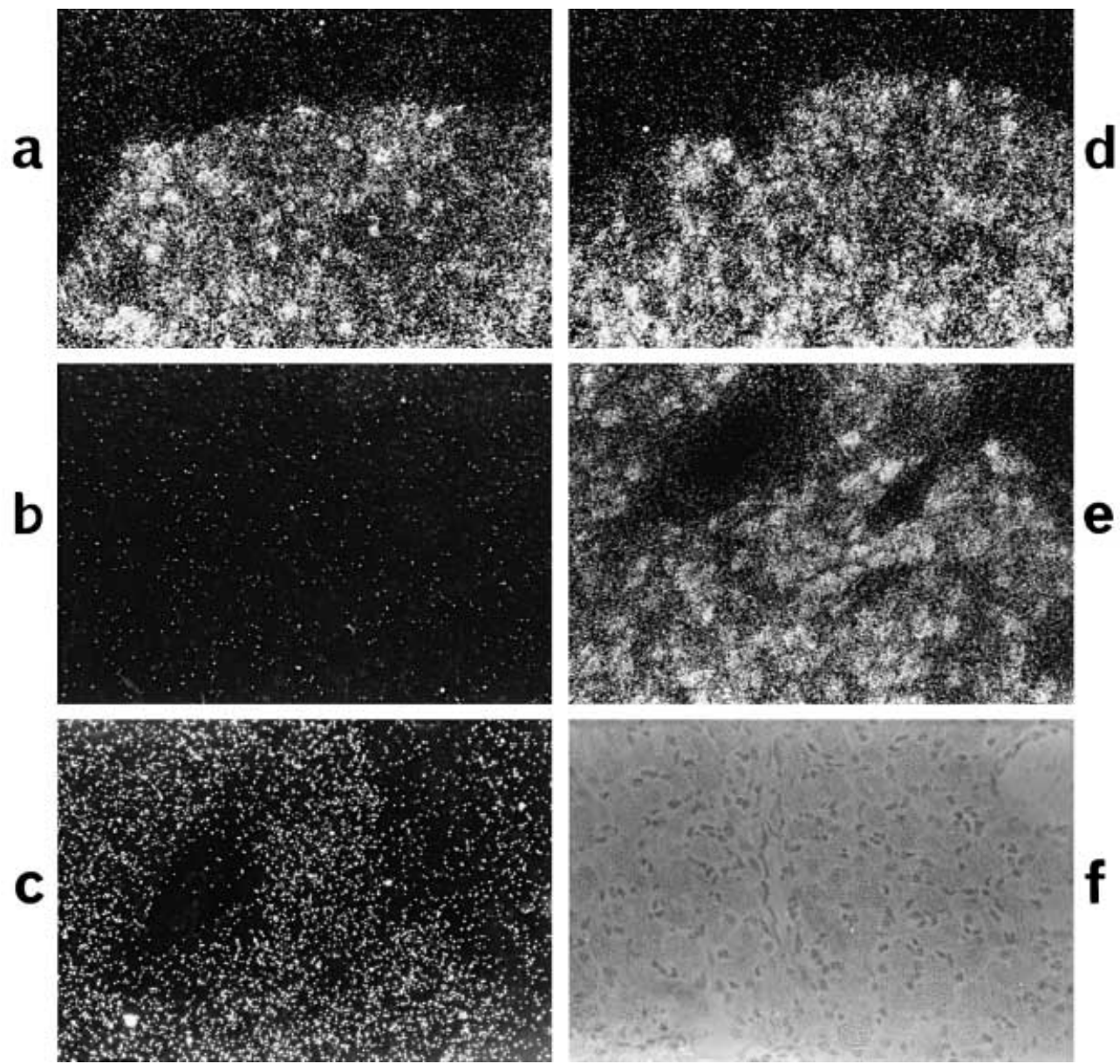

Figure 3 Binding of radiolabelled IGF-I to corpora lutea from late gestation. (a, f) Total binding; (b-e) nonspecific binding (these sections were incubated with ${ }^{125}$ I-labelled IGF-I and an excess of IGF-I (300 ng/100 $\mu \mathrm{l}$, (b)), IGF-II (300 ng/100 $\mu \mathrm{l}$, (c)), LR ${ }^{3}$ IGF-I (400 ng/100 $\mu \mathrm{l}$, (d)), or insulin $(10 \mu \mathrm{g} / 100 \mu \mathrm{l}$, (e)) simultaneously). (a-e) Darkfield $(\times 77)$; $(\mathrm{f})$ brightfield $(\times 144)$.

and large follicles (Maruo et al. 1988) and the expression of IGF-I receptor mRNAs in granulosa cells of developing and dominant healthy follicles (Zhou et al. 1996). In other cell types (thecal cells of healthy and atretic follicles and granulosa cells of atretic follicles) and in the antrum, our data show that IGF-I binding was not displaced by $\mathrm{LR}^{3}$ IGF-I, suggesting the presence of binding proteins, rather than of receptors. This result is consistent with the localization of IGF-I receptor mRNAs exclusively in granulosa cells of healthy follicles (Zhou et al. 1996). However, it contrasts with the data of Caubo et al. (1989), who demonstrated the presence of specific IGF-I receptors in thecal cells from large follicles. Moreover, IGF-I has been demonstrated to modulate in vitro steroidogenesis of porcine thecal cells (Caubo et al. 1989, Engelhardt et al. 1991). Using our method, we cannot exclude that a minor population of IGF-I binding in thecal cells and in apoptotic granulosa cells was due to specific receptors. Concerning
IGFBPs in swine ovaries, the expression of IGFBP-2 and -4 mRNAs has been reported in granulosa and thecal cells throughout the follicular development (Zhou et al. 1996), and the presence of IGFBP-2, -3 and -4 has been demonstrated in follicular fluid, IGFBP-2 being most related to atresia and IGFBP-3 to preovulatory maturation (Mondschein et al. 1991, Grimes et al. 1994).

The labelling with IGF-I observed in corpora lutea, poorly displaced by $\mathrm{LR}^{3} \mathrm{IGF}-\mathrm{I}$ or insulin, indicates the presence of large amounts of binding proteins and low levels of receptors in corpora lutea. Similarly, low expression of IGF-I receptor mRNAs and high expression of IGFBPs have been reported in porcine corpora lutea from the luteal phase (Zhou et al. 1996).

We demonstrated the presence of binding sites for insulin in the ovaries of pigs. Since insulin is known to bind insulin receptors with high affinity and type-I receptors with low affinity, and to have no affinity for type-II 


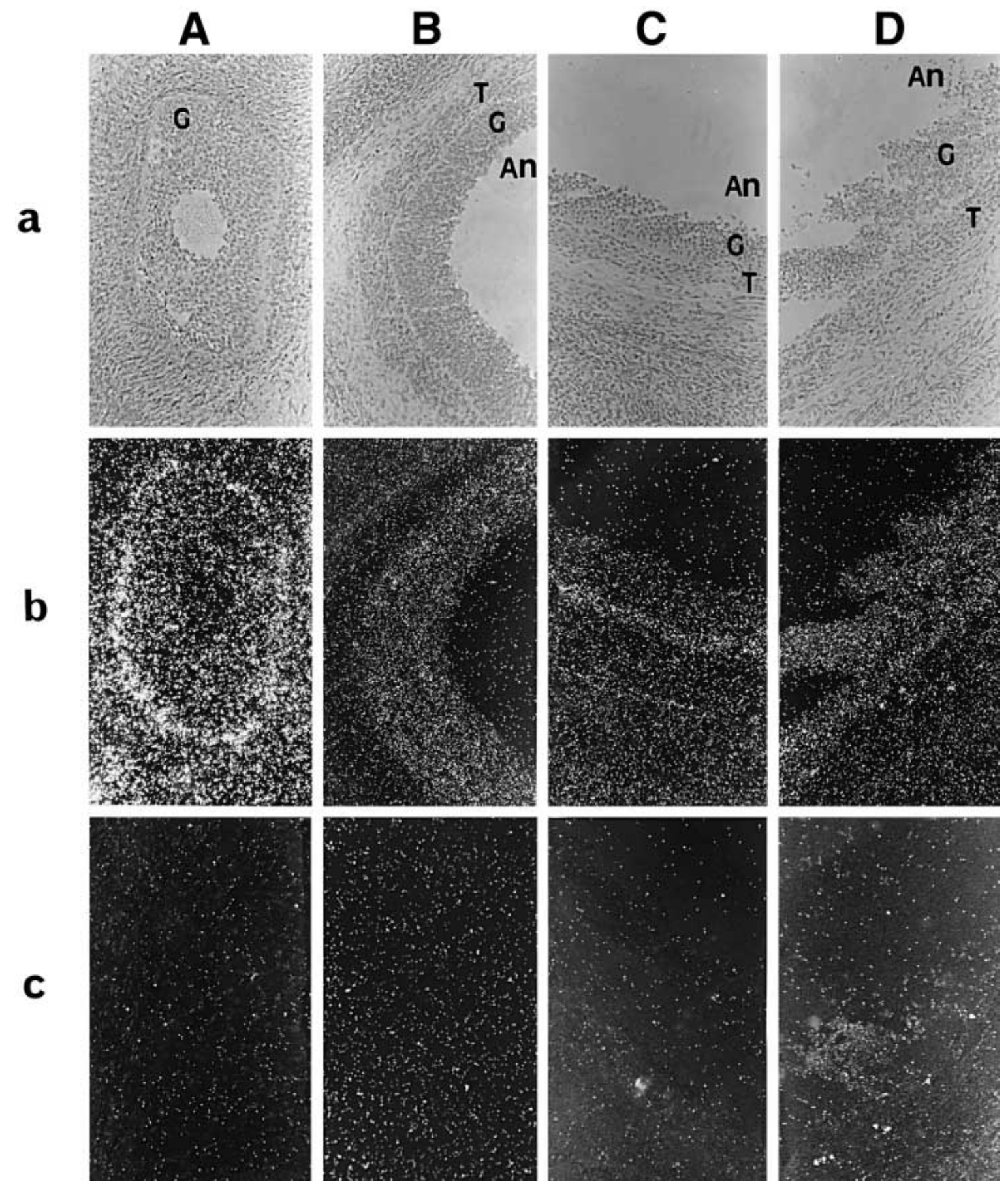

Figure 4 Binding of radiolabelled insulin to different compartments of the swine ovary. (A) Preantral follicle; (B) small antral follicle (2 mm); (C) large antral follicle $(5 \mathrm{~mm})$; (D) atretic follicle. (a, b) Total binding; (c) nonspecific binding on the same follicle (these sections were incubated with ${ }^{125}$-labelled insulin and an excess of insulin $(200 \mathrm{ng} / 100 \mu \mathrm{l})$ simultaneously). (a) Brightfield; (b, c) darkfield $(\times 76)$. An: antrum, G: granulosa cells, T: theca interna cells.

receptors and IGFBPs (reviewed by Giudice 1992), and since unlabelled insulin completely competed for the labelled ligand (present data), these binding sites represent mainly specific receptors for insulin. They were localized in stroma and in oocytes, granulosa and thecal cells (interna and externa) of preantral, small antral and large follicles and 

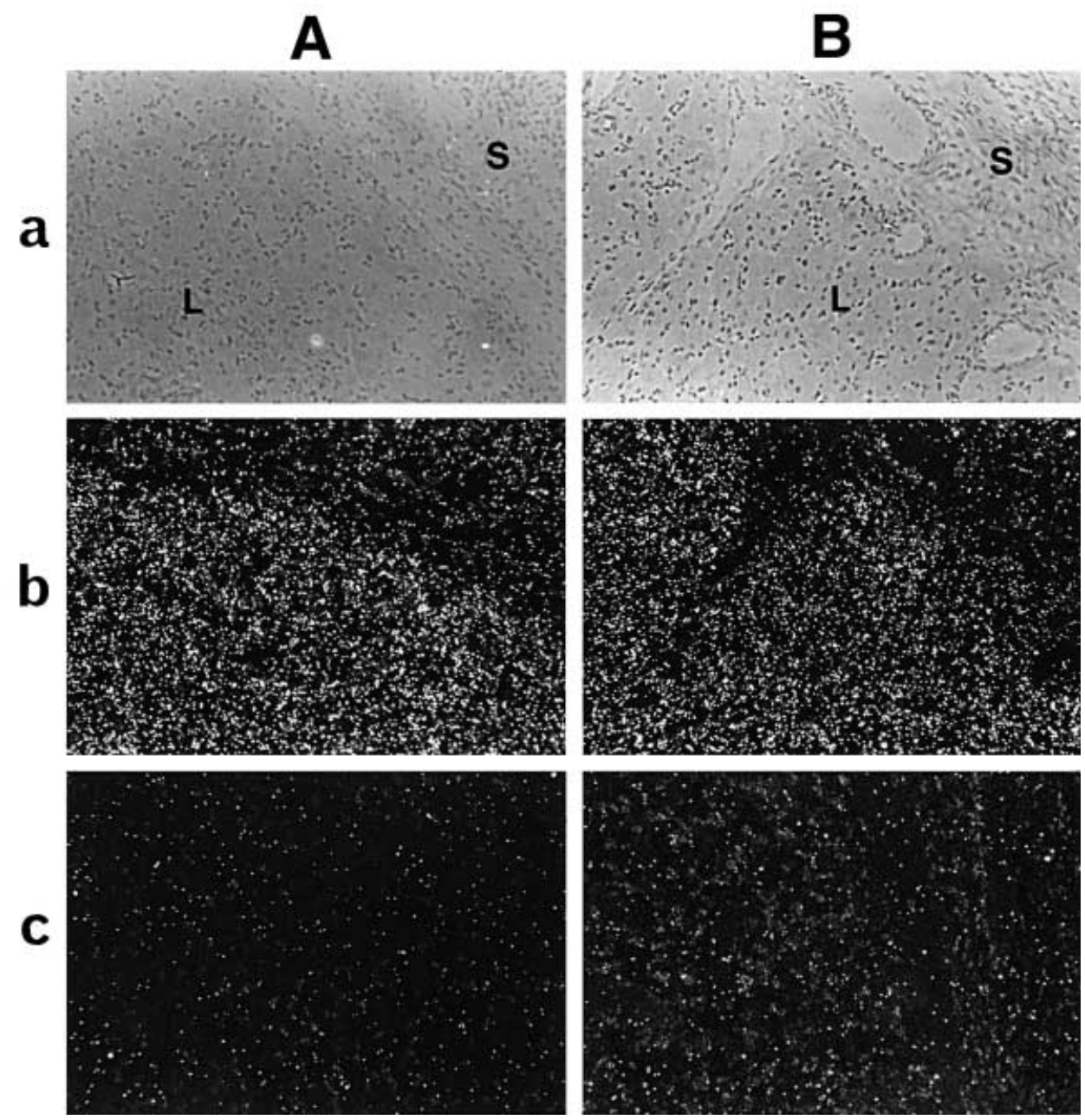

Figure 5 Binding of radiolabelled insulin to corpora lutea. (A) During the mid-luteal phase; (B) during late gestation. $(\mathrm{a}, \mathrm{b})$ Total binding; (c) nonspecific binding (these sections were incubated with ${ }^{125} \mathrm{I}$-labelled insulin and an excess of insulin $(200 \mathrm{ng} / 100 \mu \mathrm{l})$ simultaneously). (a) Brightfield; (b, c) darkfield ( $\times 84)$. S: stromal cells, L: luteal cells.

in luteal cells. Similarly, insulin receptors or corresponding mRNAs have been reported in human ovary in stroma, granulosa and theca cells and oocytes of growing follicles (Poretsky et al. 1985, El-Roeiy et al. 1993, Samoto et al. 1993), as well as in rat and human luteal cells (Ladenheim et al. 1984, Samoto et al. 1993). In pigs, the presence of insulin receptors has been previously investigated only in granulosa cells and their presence has been detected (Rein \& Schomberg 1982, Otani et al. 1985). A role for insulin has been described in follicular and luteal steroidogenesis (Veldhuis et al. 1983, Otani et al. 1985, Caubo et al. 1989, Morley et al. 1989), in oocyte maturation (Tsafiri \& Channing 1975) and in glucose metabolism of granulosa cells (Otani et al. 1985, Weber \& LaBarbera 1988). In our study, atretic follicles also presented a clear labelling in granulosa and thecal cells. In women, insulin receptor
mRNAs have been detected in pycnotic granulosa cells (El-Roeiy et al. 1993), whereas no immunoreactivity for insulin receptor has been revealed in atretic follicles (Samoto et al. 1993). The presence of insulin receptor in granulosa and theca interna of atretic and healthy follicles, as well as in corpora lutea of both stages, may suggest that this receptor is constitutively expressed in pigs.

We demonstrated that $\mathrm{bGH}$ binding sites presented a widespread distribution in the swine ovary. The use of $\mathrm{bGH}$ for in situ binding avoids confusion between somatotrophic and lactogenic sites, since bGH binds only GH sites without affinity for prolactin binding sites (Posner et al. 1974, Ranke et al. 1976). The method, however, did not allow unequivocal distinction between binding to $\mathrm{GH}$ receptor and binding to GH-binding proteins (GHBPs). The observation of a single mRNA transcript encoding for 

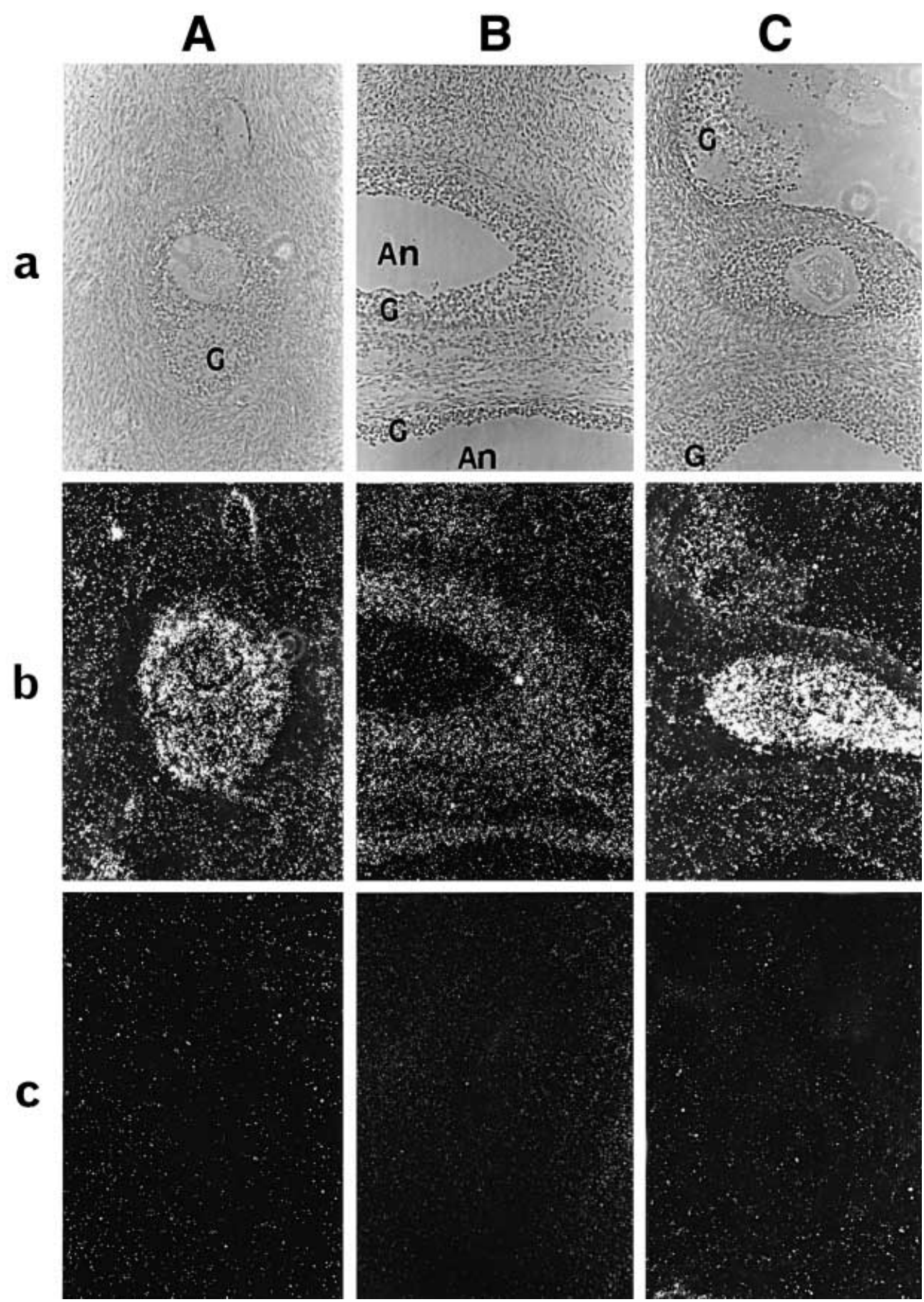

Figure 6 Binding of radiolabelled bGH to different compartments of the swine ovary. (A) Preantral follicle; (B) small antral $(2 \mathrm{~mm})+$ large antral follicles $(5 \mathrm{~mm})$; (C) preantral+antral healthy $(3-4 \mathrm{~mm}$, lower $)+$ atretic ( $5 \mathrm{~mm}$, upper) follicles. (a, b) Total binding; (c) nonspecific binding on the same follicle (these sections were incubated with ${ }^{125} \mathrm{I}$-labelled bGH and an excess of bGH (400 ng/100 $\left.\mu \mathrm{l}\right)$ simultaneously). (a) Brightfield; (b, c) darkfield ( $\times 77)$. An: antrum, G: granulosa cells. 
$\mathrm{GH}$ receptor in porcine liver and muscle supports the hypothesis that GHBPs arise from GH receptors by proteolysis (Schnoebelen-Combes et al. 1996). This suggests that the presence of GHBPs is related to the presence of GH receptors. Moreover, ${ }^{125}$ I-labelled bGH specific binding has been observed in microsomal membrane proteins of whole ovaries and Scatchard analysis has revealed the presence of a single binding site of high affinity $\left(K_{\mathrm{a}}=2 \cdot 8-3.4 \times 10^{9} \mathrm{l} / \mathrm{mol}\right.$, data not shown). We may therefore argue that binding sites detected in the present study are, at least in part, GH receptors.

Our data show binding sites for bGH in follicular cells, as well as in oocytes of preantral and small antral follicles. The presence of $\mathrm{GH}$ receptor mRNAs has been recently reported in oocytes of preantral and small antral follicles in the ewe (Eckery et al. 1997) and the cow (Kölle et al. 1998). While receptors for GH or mRNAs have been previously localized in the corpus luteum of all species tested (in rats, Lobie et al. 1990; in heifers, Lucy et al. 1993a; in humans, Sharara \& Nieman 1994; in pigs, Yuan \& Lucy 1996), various data have been reported concerning follicular localization. In the present study, GH binding sites were detected in granulosa and thecal cells of follicles from the preantral to the preovulatory stage. In heifers, Lucy et al. (1993a) observed neither immunoreactivity nor mRNAs for GH receptors in follicles of any size, whereas Kölle et al. (1998) reported the expression of GH receptor mRNAs and protein in oocyte and granulosa cells of primary and secondary follicles and in the cells of the cumulus oophorus in tertiary follicles. In humans, mRNAs coding for GH receptor were detected in granulosa cells of antral and dominant follicles, but not in preantral follicles, theca interna and externa cells, oocytes or stroma (Sharara \& Nieman 1994). In adult rats, only moderate immunoreactivity for GH receptors appeared in follicles (Lobie et al. 1990). In pigs, Yuan \& Lucy (1996) failed to detect any $\mathrm{GH}$ receptor mRNAs in small antral follicles in porcine ovary on day 10 of the oestrous cycle, whilst in sheep Eckery et al. (1997) reported mRNAs for GH receptors in granulosa cells of small antral follicles.

In cattle, Webb et al. (1994) have suggested that the increase in the number of small- or medium-sized follicles following administration of GH (Gong et al. 1991, Lucy et al. 1993b) was more likely due to the increase in either IGF-I, insulin or both than to a direct effect of GH on follicles. Administration of $\mathrm{GH}$ to cyclic gilts has been demonstrated to increase ovulation rate (Kirkwood et al. 1988) and the number of medium-sized, but not of small-sized, antral follicles (Echternkamp et al. 1994). The presence of $\mathrm{GH}$ binding sites in follicles suggests that, in gilts, GH effects may be mediated by GH receptors and not necessarily by IGF-I action at the ovarian level. Cattle and pigs may thus differ with respect to the action of $\mathrm{GH}$ on follicular growth. In the present study, the intensity of GH binding on granulosa cells seemed to be inversely related to the follicular size, being strong in preantral and small antral follicles and barely detectable in preovulatory follicles. Moreover, these binding sites are undetected in atretic follicles. This may imply that $\mathrm{GH}$ has a direct role, particularly important in early stages of folliculogenesis, when follicular growth does not require the action of gonadotrophins (Driancourt et al. 1995).

In conclusion, present data support the participation of IGF-I, insulin and GH in the process of follicular growth and suggest that their action is, at least in part, mediated through their specific receptors.

\section{Acknowledgements}

The author wishes to acknowledge the staff in Saint-Gilles for taking care of the animals, Y Lebreton for performing the surgical procedures, A Pasquier for her technical assistance, P Ecolan for his help in the photographic work and I Louveau for providing ${ }^{125}$ I-labelled IGF-I and bGH. bGH was a gift from the USDA Animal Hormone Program, Beltsville, MD, USA. The author also thanks A Prunier (INRA, Saint-Gilles, France), D Monniaux and P Monget (INRA, Nouzilly, France) for critical evaluation of the manuscript.

\section{References}

Adashi EY, Resnick CE, D'Ercole AJ, Svoboda ME \& Van Wyk JJ 1985 Insulin-like growth factors as intraovarian regulators of granulosa cell growth and function. Endocrine Reviews 6 400-420.

Breier BH, Gluckman PD, Blair HT \& McCutcheon SN 1989 Somatotrophic receptors in hepatic tissue of the developing male pig. Journal of Endocrinology 116 169-177.

Caubo B, DeVinna RS \& Tonetta SA 1989 Regulation of steroidogenesis in cultured porcine theca cells by growth factors. Endocrinology 125 321-326.

Cosgrove JR \& Foxcroft GR 1996 Nutrition and reproduction in the pig: ovarian aetiology. Animal Reproduction Science 42 131-141.

Cox NM 1997 Control of follicular development and ovulation rate in pigs. Journal of Reproduction and Fertility (Suppl.) 52 31-46.

Cox NM, Stuart MJ, Althen TG, Bennett WA \& Miller HW 1987 Enhancement of ovulation rate in gilts by increasing dietary energy and administering insulin during follicular growth. Journal of Animal Science 64 507-516.

Driancourt MA, Locatelli A \& Prunier A 1995 Effects of gonadotrophin deprivation on follicular growth in gilts. Reproduction, Nutrition, Development 35 663-673.

Echternkamp SE, Spicer LJ, Klindt J, Vernon RK, Yen JT \& Buonomo FC 1994 Administration of porcine somatotropin by a sustained-release implant: effects on follicular growth concentrations of steroids and insulin-like growth factor I, and insulin-like growth factor binding protein activity in follicular fluid of control, lean, and obese gilts. Journal of Animal Science 72 2431-2440.

Eckery DC, Moeller CL, Nett TM \& Sawyer HR 1997 Localization and quantification of binding sites for follicle-stimulating hormone, luteinizing hormone, growth hormone, and insulin-like growth factor I in sheep ovarian follicles. Biology of Reproduction $\mathbf{5 7}$ 507-513.

El-Roeiy A, Chen X, Roberts VJ, LeRoith D, Roberts CT \& Yen SSC 1993 Expression of insulin-like growth factor-I (IGF-I) and 
IGF-II and the IGF-I, IGF-II, and insulin receptor genes and localization of the gene products in the human ovary. Journal of Clinical Endocrinology and Metabolism 77 1411-1418.

Engelhardt H, Gore-Langton RE \& Armstrong DT 1991 Luteinization of porcine cells in vitro. Molecular and Cellular Endocrinology $\mathbf{7 5}$ 237-245.

Francis GL, Ross M, Ballard FJ, Milner SJ, Senn C, McNeil KA, Wallace JC, King R \& Wells JRE 1992 Novel recombinant fusion protein analogues of insulin-like growth factor (IGF)-I indicate the relative importance of IGF-binding protein and receptor binding for enhanced biological potency. Journal of Molecular Endocrinology 8 213-223.

Giudice LC 1992 Insulin-like growth factors and ovarian follicular development. Endocrine Reviews 13 641-669.

Gong JG, Bramley T \& Webb R 1991 The effect of recombinant somatotropin on ovarian function in heifers: follicular populations and peripheral hormones. Biology of Reproduction 45 941-949.

Grimes RW, Barber JA, Shimasaki S, Ling N \& Hammond JM 1994 Porcine ovarian granulosa cells secrete insulin-like growth factorbinding proteins- 4 and -5 and express their messenger ribonucleic acids: regulation by follicle-stimulating hormone and insulin-like growth factor-1. Biology of Reproduction 50 695-701.

Hsu C-J \& Hammond JM 1987 Concomitant effects of growth hormone on secretion of insulin-like growth factor I and progesterone by cultured granulosa cells. Endocrinology 121 1343-1348.

Jia X-C, Kalmijn J \& Hsueh AJW 1986 Growth hormone enhances follicle-stimulating hormone-induced differentiation of cultured rat granulosa cells. Endocrinology 118 1401-1409.

Kirkwood RN, Thacker A, Gooneratne AD, Guedo BL \& Laarveld B 1988 The influence of exogenous growth hormone on ovulation rate in gilts. Canadian Journal of Animal Science 68 1097-1103.

Kölle S, Sinowatz F, Boie G \& Lincoln D 1998 Developmental changes in the expression of the growth hormone receptor messenger ribonucleic acid and protein in the bovine ovary. Biology of Reproduction 59 836-842.

Ladenheim RG, Tesone M \& Charreau EH 1984 Insulin action and characterization of insulin receptors in rat luteal cells. Endocrinology $115752-756$.

Lobie PE, Breipohl W, Garcia Aragon J \& Waters MJ 1990 Cellular localization of the growth hormone receptor/binding protein in the male and female reproductive systems. Endocrinology 126 2214-2221.

Lucy MC, Collier RJ, Kitchell ML, Dibner JJ, Hauser SD \& Krivi GG 1993a Immunohistochemical and nucleic acid analysis of somatotropin receptor populations in the bovine ovary. Biology of Reproduction 48 1219-1227.

Lucy MC, De La Sota RL, Staples CR \& Thatcher WW 19936 Ovarian follicular populations in lactating dairy cows treated with recombinant bovine somatotropin (sometribove) or saline and fed diets differing in fat content and energy. Journal of Dairy Science 76 1014-1027.

Manson HD, Martkaninen H, Beard RW, Anayaoku V \& Franks S 1990 Direct gonadotropic effect of growth hormone on oestradiol production by human granulosa cells in vitro. Journal of Endocrinology 126 R1-R4.

Maruo T, Hayashi M, Matsuo H, Ueda Y, Morikawa H \& Mochizuki M 1988 Comparison of a facilitative roles of insulin and insulin-like growth factor I in the functional differentiation of granulosa cells: in vitro studies with the porcine model. Acta Endocrinologica 117 230-240.

Mondschein JS, Etherton TD \& Hammond JM 1991 Characterization of insulin-like growth factor-binding proteins of porcine ovarian follicular fluid. Biology of Reproduction 44 315-320.

Monget P, Monniaux D \& Durand P 1989 Localization, characterization, and quantification of insulin-like growth factor-I-binding sites in the ewe ovary. Endocrinology 125 2486-2493.
Morley P, Calaresu FR, Barre GJ \& Armstrong DT 1989 Insulin enhances luteinizing hormone-stimulated steroidogenesis by porcine theca cells. Biology of Reproduction 40 735-743.

Okere C, Hacker RR \& Werchola G 1996 Enhancing cyclic activity and reproductive performance of post-weaned sows via potent IGF-I. Journal of Animal Science 74 (Suppl 1) 249.

Otani T, Maruo T, Yukimura N \& Mochizuki M 1985 Effect of insulin on porcine granulosa cells: implications of a possible receptor mediated action. Acta Endocrinologica 108 104-110.

Poretsky L, Grigorescu F, Seibel M, Moses AC \& Flier JS 1985 Distribution and characterization of insulin and insulin-like growth factor I receptors in normal human ovary. Journal of Clinical Endocrinology and Metabolism 61 728-734.

Posner BI, Kelly PA, Shiu PC \& Friesen HG 1974 Studies of insulin, growth hormone and prolactin binding: tissue distribution, species variation and characterization. Endocrinology 95 521-531.

Ramirez JL, Cox NM \& Moore AB 1997 Influence of exogenous insulin before breeding on conception rate and litter size of sows. Journal of Animal Science 75 1893-1898.

Ranke MB, Stanley CA, Tenore A, Robard D, Bongiovani AM \& Parks JS 1976 Characterization of somatogenic and lactogenic binding sites in isolated rat hepatocytes. Endocrinology $\mathbf{9 9}$ 1033-1045.

Rein MS \& Schomberg DW 1982 Characterization of insulin receptors on porcine granulosa cells. Biology of Reproduction 26 (Suppl 1) 113.

Samoto T, Maruo T, Ladines-Llave CA, Matsuo H, Deguchi J, Barnea ER \& Mochizuki M 1993 Insulin receptor expression in follicular and stromal compartments of the human ovary over the course of follicular growth, regression and atresia. Endocrine Journal 40 715-726.

Schnoebelen-Combes S, Louveau I, Postel-Vinay MC \& Bonneau M 1996 Ontogeny of GH receptor and GH-binding protein in the pig. Journal of Endocrinology 148 249-255.

Sharara FI \& Nieman LK 1994 Identification and cellular localization of growth hormone receptor gene expression in the human ovary. Journal of Clinical Endocrinology and Metabolism 79 670-672.

Tsafiri A \& Channing CP 1975 Influence of follicular maturation and culture conditions on the meiosis of pig oocytes in vitro. Journal of Reproduction and Fertility 43 149-152.

Veldhuis JD, Kolp LA, Toaff ME, Strauss JF \& Demers LM 1983 Mechanisms subserving the trophic actions of insulin on ovarian cells. Journal of Clinical Investigation 72 1046-1057.

Webb R, Gong JG \& Bramley TA 1994 Role of growth hormone and intrafollicular peptides in follicle development in cattle. Theriogenology 41 25-30.

Weber SL \& LaBarbera AR 1988 Insulin, somatomedin-C, human chorionic gonadotropin, and forskolin enhance glucose oxidation by granulosa cells. Biology of Reproduction 38 812-816.

Yuan W \& Lucy MC 1996 Messenger ribonucleic acid expression for growth hormone receptor, luteinizing hormone receptor, and steroidogenic enzymes during the estrous cycle and pregnancy in porcine and bovine corpora lutea. Domestic Animal Endocrinology 13 431-444.

Zhou J, Adesanya OO, Vatzias G, Hammond JM \& Bondy CA 1996 Selective expression of insulin-like growth factor system components during porcine ovary follicular selection. Endocrinology 1374893 4901.

Received 21 December 1998

Revised manuscript received 22 March 1999

Accepted 16 June 1999 